\title{
Asians in Aotearoa New Zealand: A population of interest for social work
}

Hagyun Kim, Massey University, Aotearoa New Zealand

\begin{abstract}
Aotearoa New Zealand is a country where cultural differences are widespread and longstanding. The Treaty of Waitangi laid the foundation for an inclusive society where citizens' full participation is granted. Nevertheless, a number of Asians seem to have limited access to the benefits of an inclusive society, with great concerns over social isolation and marginalisation. This requires social workers attend to Asians' life challenges, justified by key principles of human rights and social justice; yet a paucity of training exists in social work education, limiting their ability to work with this population. More training is necessary in the social work curriculum through which social workers enhance cultural competence, with relevant knowledge and skills, in relation to working with Asians in Aotearoa New Zealand.
\end{abstract}

Keywords: Asians; cultural competence; social work education

Last summer, I visited the Chinese Settlement in Arrowtown where I found a plate at the front stating "Chinese gold miners - Invited but Unwelcome." I believe this brief sentence well captures society's reception towards them historically. On the way back to my hotel, I felt saddened by the fact that the current society's reception towards Asians has not much changed, or perhaps has been worsened since ethnic divisions at this time seem to have only intensified (Weld \& Appleton, 2008). This article is based on my reflections upon teaching social work students who rarely have direct interactions with Asians, and subsequently do not have an opportunity to learn about their life challenges.

As a scholar in immigration studies, I acknowledge that one of noticeable outcomes of globalisation is the age of immigration (Castles \& Miller, 2009), with resultant increased ethnic diversity in modern societies. Aotearoa New Zealand is not exempt from this global phenomenon, in that a quarter of its residents were born overseas in 2018

(Statistics New Zealand, n.d.), and this demographic change has transformed citizens' every interaction as well as the reality social workers encounter on a daily basis.

Currently, social workers inevitably engage with people who have different cultural and linguistic backgrounds, including their colleagues. Indeed, many social workers already work for social services where the programmes primarily target specific ethnic groups' life challenges. In this sense, as an educator in social work, I emphasise the need for training to explore and understand the wide range of issues involved in working with Asians. This position is echoed by the practice standards of both the Aotearoa New Zealand Association of Social Workers (ANZASW, 2018) and the Social Workers Registration Board (SWRB, 2016) which requests its members to work inclusively and respectfully with different ethnic and cultural groups. Having said that, this article questions "Where can social workers learn or obtain the relevant knowledge and skills?"
AOTEAROA

NEW ZEALAND SOCIAL WORK 33(4), 77-81.

CORRESPONDENCE TO: Hagyun Kim H.kim2@massey.ac.nz 
While social workers work with "ethnically and linguistically diverse communities" (Goh, 2019 , p. 48), I am concerned that the lack of training related to Asians' life challenges may limit their capacity to comply with the practice standards described earlier. A paucity of training appears in the social work curriculum for social workers to be exposed to and understand Asians' narratives, despite Asians comprising $15.1 \%$ of the total population in 2018 (Statistics New Zealand, n.d.). For example, although there are cultural courses pertaining to biculturalism and the Pacific model, no tertiary education institutes (TEIs) currently offer training programmes specifically related to working with Asians in New Zealand. At best, some of their courses contain multicultural discourses, but lack a focus on Asians' experiences in New Zealand (Massey University, n.d.; The University of Auckland, n.d.). Training where social workers learn the characteristics of Asians in historical and social arrangements, while critically considering their position in society, is a necessity in social work education.

\section{Understanding Asians within the immigration context}

Immigration has been an integral part of Aotearoa New Zealand society since 1840 when Māori signed the Treaty of Waitangi. Since then, British setters have been the main source of immigrants as the then government wished to entrench the interests of British imperialism (Bedford et al., 2010). Accordingly, numbers of Asians were historically kept low by all possible legislative means, including a poll tax on Chinese immigrants (1881-1914) (King, 2003) and the Old Age Pension Act 1898 which denied Chinese or other Asiatics' access to pensions (Te Ara, n.d.).

Having said that, although the first numbers of Chinese miners arrived in this country a few years after the British settlers, the presence of Asians was broadly invisible in society (Hoadley, 2003), remaining under $1 \%$ of the total population until the 1990 s
(Jackson \& McRobie, 2005), and being forced to maintain a sojourner community (McKinnon, 1996). As such, the legacy of the colonisation has resulted in a dominant culture of whiteness in Aotearoa New Zealand society (Chenoweth \& McAuliffe, 2021) where many Asians experience a wide range of inequality, compounded by discrimination and racism, in relation to the majority-minority cultures. According to the Social Report in 2016, Asians were identified as the most discriminated against group in New Zealand society (Ministry of Social Development, 2016).

The dominance of British settlers lasted until changes to immigration laws ensued in the 1980s which abolished racial preference (Cheyne et al., 2008). Since then, society has witnessed such a massive inflow of Asians that, currently, 707,598 Asians reside throughout New Zealand in 2018 (Statistics New Zealand, n.d.) boosting the Asian population from less than $1 \%$ of the total population in the early 1980 s to $15.1 \%$ of the total population today. In this sense, I refer to the majority of Asians as immigrants, though I acknowledge their presence in Aotearoa New Zealand since the early 1800s (King, 2003) as well as the existence of Asians entering Aotearoa New Zealand as refugees (Kim \& Cooper, 2021). Currently, Chinese $(231,387)$ is the largest Asian ethnic group, followed by Indian $(221,916)$, Filipino $(72,612)$ and Korean $(30,792)$ (Statistics New Zealand, n.d.).

Meanwhile, it should be noted that categorising all Asians as one group is almost impossible and problematic due to their greater diverse variations (Ho, 2015). "Asians" are people from a vast region that contains over $60 \%$ of the world's population, east of (and including) Afghanistan, and south of (and including) China (Ministry of Health, 2006). Each Asian ethnic group has their own unique cultural and linguistic background, education and socio-economic status. Additionally, a number of Asians in Aotearoa New Zealand are refugees who fled from South-East Asian countries 
such as Cambodia and Vietnam during the 1970s and, more recently, Afghanistan and Myanmar. Since they are people who are forcibly pushed into an alien environment (Ward et al., 2001), their experiences inevitably differ from those Asians who have relocated voluntarily for long-term resettlement. Significant differences exist within the Asian community itself; that is to say, there are "multiple dimensions of difference within Aotearoa New Zealand's Asian communities" (Ho, 2015, p. 97).

Nevertheless, while recognising their different demographic characteristics, cultures, and languages, I suggest social workers begin to examine Asians' life challenges in the context of immigration. Since the majority of them in Aotearoa New Zealand today have lived here for less than three decades, Asians, regardless of their status of entry, have settlement issues in common. In other words, whether they are immigrants or refugees, Asians have to re-establish their lives in contexts with dramatically different social and cultural attributes (Kim \& Hocking, 2016). This would be a starting point where social workers could obtain foundational knowledge with which they can later understand the characteristics of each Asian ethnic group separately. Despite their different statuses of entry, skills and life situations, there are replicated reports that the experience Asians collectively share is of struggling to re-build their lives with an ethnic minority status. Understanding of Asians' life issues within this framework will be a pathway for social workers in relation to obtaining and improving their cultural competence in working with this population.

For many Asians, settling in a foreign country involves a profound non-normative life transition in which they strive to navigate in two cultural spaces. It is a stress-inducing process requiring extensive adaptation, influenced by a number of factors at both the social and individual levels. Asians, regardless of their status of entry, have to adapt to new and often alien surroundings (Lee \& Keown, 2018). Their ethnic minority status in society brings myriad acculturative stressors such as loss of cultural norms, language, religious customs and social support systems (Levitt et al., 2005), while their status as new arrivals results in a strong attachment to their own culture (Choi \& Thomas, 2009). From this perspective, a process of settlement includes conflict, alienation, and loss (Pepworth \& Nash, 2009) and, as a result, their potential is underestimated, which may limit their participation in civic society (Kim, 2021).

Of particular note, Asians' stories of settlement exist in social contexts (Kim \& Hocking, 2016). The stresses of life transition to the host society are all magnified when they encounter a prejudiced social reception (Abbott et al., 2000), while being forced to carry a sense of otherness in society (Ho, 2015). The historically embedded ethnic inequality has been perpetuated by ethnically biased social policy (Cheyne et al., 2008) whereby Asians' membership is continually denied in society $(\mathrm{Ng}, 2017)$. This inequality can be witnessed today in the Covid-19 pandemic, when many Asians report Covidfuelled discrimination and racism (Nielsen, 2021), while race pay inequity persists (Anthony, 2015) and Asians' membership as citizens continues to be judged by the attitudes of the host society (Kim, 2021).

From my reflections in teaching social work students, some found this point to be exaggerated, in particular for those who believe in this country's carefully constructed racial harmony (Duncan, 2007), questioning whether it is the case that all Asians are in despair. Of course, the answer to this, is no. I do not deny that there are numerous cases of successful Asians in certain areas of social settings such as health, education, and employment. Such cases could arguably even include the author who has an Asian immigrant background. I do appreciate societal efforts towards Asians' success and the fact that more New Zealanders are beginning to perceive Asians' positive contribution to the 
society (Ministry of Business, Innovation and Employment (MBIE), 2015). However, what I emphasise in this article is that it is equally important to note that, despite societal efforts to enhance Asians' participation in society, the history of anti-Asian racism still remains in Aotearoa New Zealand (Cheyne et al., 2008), resulting in formidable barriers for many Asians to obtain equal citizenship ( $\mathrm{Ng}, 2017)$. Many Asians' stories of loss often become stories of despair when they face unwelcoming attitudes from the receiving society, and this experience undermines their perception of identity and well-being.

\section{Asians in social work education}

For Asians, their ethnic minority status often confines their involvement in the host community, leading to their high levels of social isolation and economic marginalisation (Ho, 2015; Kim \& Hocking, 2016; Lee \& Keown, 2018). Such disruption potentially devalues their sense of self, as a person's sense of self emerges largely as a result of his/her everyday experiences (Wilcock \& Hocking, 2015), and given that health is created by a person's daily experiences (WHO, 2001), increasing numbers of Asians are at a higher risk of diverse health problems-in particular mental health problems such as anxiety and depression (Kim et al., 2010).

Based on this concern, I postulate that Asians should be defined as a population of interest for social work in Aotearoa New Zealand; this is justified by key principles of human rights and social justice (Chenoweth $\&$ McAuliffe, 2021). Since it professionally emerged in the 19th century, social work has always worked with profoundly vulnerable populations, which are overwhelmed by oppressive lives and by circumstances they are powerless to control (Doel, 2012). In this sense, the scope of social work in Aotearoa New Zealand must grow to embrace the Asian population, and this requires social workers to improve cultural competence including their tolerance for differences, their understanding of various cultural norms, and their ability to cross-culturally communicate (Abrams \& Gibson, 2007).

Educators in social work have a responsibility to provide a sound educational opportunity through which social workers obtain the required knowledge and skills for their practice. To work with Asians, relevant knowledge and skills include the history of immigration, institutional racism and its impact on people, the acculturation model, theories underpinned by anti-racism and social justice, and crosscultural skills for culturally appropriate and sensitive assessments and interventions. Social work is a profession which exercises judgement in the face of complex and competing interests and claims. To that end, curriculum content on working with Asians is required where social workers understand ways of conceptualising differences while critically reflecting on their position in society, and this effort aligns with TEIs' commitments to having programmes in which social workers learn how to work with different ethnic and cultural groups in line with the practice standards of both the ANZASW and the SWRB.

\section{Conclusion}

This viewpoint is a reflection of my experience as a scholar in immigration studies, educator in social work and practitioner working with Asians. Despite their significant proportion in society, Asians are invisible (Kim \& Hocking, 2016) and powerless in society (Nielsen, 2021). Just as in the 1800s, it seems that most Asians are invited to this country but unwelcomed by the host society. Asians are one of vulnerable populations in Aotearoa New Zealand who deserve social workers' attention in addressing their life challenges. This inevitably requires educators in social work to prepare training in which social workers learn how to effectively engage with Asians, in order for social workers to be able to meet their legal and ethical duties.

Accepted 4 December 2021

Published 23 December 2021 


\section{References}

Abbott, M. W., Wong, S., Williams, M., Au, M. K., \& Young, W. (2000). Recent Chinese migrants' health, adjustment to life in New Zealand and primary health care utilisation. Disability and Rehabilitation, 22(1/2), 43-56.

Abrams, L. S., \& Gibson, P. (2007). Reframing multicultural education: Teaching white privilege in the social work curriculum. Journal of Social Work Education, 43(1), 147-160.

Anthony, J. (2015, July 28). Gender and race discrimination hurting New Zealand financially: Lawyer Mai Chen. Stuff NZ. https://www.stuff.co.nz/business/ industries/70595477/null

Aotearoa New Zealand Association of Social Workers (ANZASW). (2018). ANZASW social work practice standards: Enhancing competent social work practice. https://anzasw.nz/wp-content/uploads/PracticeStandard-Publication-Full-Nov-14.pdf

Bedford, R., Ho, E., \& Bedford, C. (2010). Pathways to residence in New Zealand, 2003-2010. In A. Trlin, P. Spoonley, \& R. Bedford (Eds.), New Zealand and international migration: A digest and bibliography (No. 5, pp. 1-44). Massey University Press.

Castles, S., \& Miller, M. (2009). The age of migration (4th ed.). Palgrave Macmillan.

Chenoweth, L., \& McAuliffe, D. (2021). The road to social work and human service practice (6th ed.). Cengage.

Cheyne, C., O'Brien, M., \& Belgrave, M. (2008). Social policy in Aotearoa New Zealand (4th ed.). Oxford University Press.

Choi, J. B., \& Thomas, M. (2009). Predictive factors of acculturation attitudes and social support among Asian immigrants in the USA. International Journal of Social Welfare, 18, 76-84. doi:10.1111/j.14682397.2008.00567.x

Doel, M. (2012). Social work: The basics. Routledge.

Duncan, G. (2007). Society and politics: New Zealand social policy (2nd ed.). Pearson.

Goh, M. (2019). Cultural support workers in the Aotearoa New Zealand healthcare setting: Challenge and opportunity for health social work. Aotearoa New Zealand Social Work, 31(4), 48-59.

Ho, E. (2015). The changing face of Asian people in New Zealand. New Zealand Population Review, 41, 95-118.

Hoadley, S. (2003). Immigration policy. In R. Miller (Ed.), New Zealand government and politics (3rd ed., pp. 522-531). Oxford University Press.

Jackson, K., \& McRobie, A. (2005). Historical dictionary of New Zealand (2nd ed.). Scarecrow Press.

Kim, H. (2021). "Knocking on the door to integration": Korean immigrants' stories of seeking membership in Aotearoa New Zealand society. Aotearoa New Zealand Social Work, 33(1), 29-43.

Kim, H., \& Cooper, L. (2021). Refugees. In G. Hassall \& G. Karacaoglu (Eds.), Social policy practice and process in Aotearoa New Zealand (pp. 425-437). Massey University Publication.

Kim, H., \& Hocking, C. (2016). Attending to immigrants' everyday activities: A new perspective on ensuring Asian immigrants' quality of life. Aotearoa New Zealand Social Work, 28(3), 57-66.
Kim, J., Park, J., \& Heo, J. (2010). What should recreational professionals do when providing services to elderly immigrants? Physical \& Occupational Therapy in Geriatrics, 28(2), 195-202.

King, M. (2003). History of New Zealand. The Penguin Group.

Lee, B., \& Keown, L. J. (2018). Challenges and changes in the parenting experiences of Korean immigrants in New Zealand. Asian and Pacific Migration Journal, 27(4), 431-450.

Levitt, M., Lane, J., \& Levitt, J. (2005). Immigration stress, social support, and adjustment in the first postmigration year: An intergenerational analysis. Research in Human Development, 2(4), 159-177.

Massey University. (n.d.). Bachelor of Social Work. http://www.massey.ac.nz/massey/learning/programmecourse/programme.cfm?prog_id=92512

McKinnon, M. (1996). Immigrants and citizens: New Zealanders and Asian immigration in history context. Victoria University of Wellington.

Ministry of Business, Innovation and Employment (MBIE). (2015). Community perceptions of migrants and immigration. https://www.mbie.govt.nz/assets/ c3c87370d1/community-perceptions-migrantsimmigration-2015.pdf

Ministry of Health. (2006). Asian health chart book 2006. http://www.moh.govt.nz/moh.nsf/indexmh/asian-healthchart-book-2006?Open

Ministry of Social Development. (2016). The social report 2016: Te purongo oranga tangata. https://www.socialreport.msd.govt.nz/documents/2016/ msd-the-social-report-2016.pdf

Nielsen. (2021). Racism and xenophobia experiences in Aotearoa New Zealand during covid-19: A focus on Chinese and Asian communities. New Zealand Human Rights Commission.

Ng, K. E. (2017). Old Asian, new Asian. Bridget Williams Books.

Pepworth, J., \& Nash, M. (2009). Finding "a safe place to cry": A review of research and evidence informing social work with refugees and new settlers in Aotearoa New Zealand. Aotearoa New Zealand Social Work, 21(1/2), 48-59.

Social Workers Registration Board (SWRB). (2016). Code of conduct. https://swrb.govt.nz/practice/code-of-conduct/

Statistics New Zealand. (n.d.). 2018 Census ethnic group summaries. https://www.stats.govt.nz/tools/2018-censusethnic-group-summaries/

Te Ara. (n.d.). Denied the old age pension. https://teara.govt. nz/en/photograph/27298/denied-the-old-age-pension

The University of Auckland. (n.d.). Bachelor of Social Work. https://www.auckland.ac.nz/en/study/study-options/finda-study-option/bachelor-of-social-work-bsw.html

Ward, C., Bochner, S., \& Furnham, A. (2001). The psychology of culture shock (2nd ed.). Routledge.

Weld, N., \& Appleton, C. (2008). Walking in people's worlds. Pearson.

Wilcock, A. A., \& Hocking, C. (2015). An occupational perspective of health (3rd ed.). Slack. 